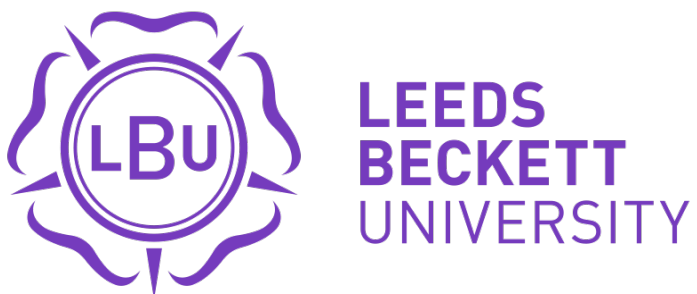

Citation:

Dart, J (2013) Representations of sport in the revolutionary socialist press in Britain, 1988-2012. International Review for the Sociology of Sport, 50 (8). 993 - 1015. ISSN 1012-6902 DOI: https://doi.org/10.1177/1012690213497352

Link to Leeds Beckett Repository record:

https://eprints.leedsbeckett.ac.uk/id/eprint/187/

Document Version:

Article (Accepted Version)

This is the authors' final version of this article, typesetting / pagination may vary from the published version which should be used for reference and citation.

The aim of the Leeds Beckett Repository is to provide open access to our research, as required by funder policies and permitted by publishers and copyright law.

The Leeds Beckett repository holds a wide range of publications, each of which has been checked for copyright and the relevant embargo period has been applied by the Research Services team.

We operate on a standard take-down policy. If you are the author or publisher of an output and you would like it removed from the repository, please contact us and we will investigate on a case-by-case basis.

Each thesis in the repository has been cleared where necessary by the author for third party copyright. If you would like a thesis to be removed from the repository or believe there is an issue with copyright, please contact us on openaccess@leedsbeckett.ac.uk and we will investigate on a case-by-case basis. 


\title{
Representations of sport in the revolutionary socialist press in Britain, 1988-2012
}

Jon Dart

\begin{abstract}
This paper considers how sport presents a dualism to those on the far left of the political spectrum. A long-standing, passionate debate has existed on the contradictory role played by sport, polarised between those who reject it as a bourgeois capitalist plague and those who argue for its reclamation and reformation. A case study is offered of a political party that has consistently used revolutionary Marxism as the basis for its activity and how this party, the largest in Britain, addresses sport in its publications. The study draws on empirical data to illustrate this debate by reporting findings from three socialist publications. When sport did feature it was often in relation to high profile sporting events with a critical tone adopted and typically focused on issues of commodification, exploitation and alienation of athletes and supporters. However, readers' letters, printed in the same publications, revealed how this interpretation was not universally accepted, thus illustrating the contradictory nature of sport for those on the far left.
\end{abstract}

Keywords: capitalism, Marxism, socialism, Socialist Workers Party, working class

\section{Introduction}

A long-standing, passionate debate over sport has existed amongst those on the revolutionary left, polarised between those who reject sport as a bourgeois capitalist plague and those who seek to enjoy sport sui generis and/or seek to use it to advance socialist ideas. A popular perception exists which sees the revolutionary left dismiss sport as a site of, and for, excessive nationalism, sexism, racism, homophobia and class bias; yet, there is another perspective which argues for the reclamation and reformation of sport. However, until now, much of the debate has been based on abstract theory and lacking reference to empirical data. This study seeks to correct this by offering an empirical informed discussion on how sport is viewed by the largest party on the revolutionary left in contemporary Britain.

The paper focuses on a political party that has consistently used revolutionary Marxist ideology as a basis for its activity. A content and discourse analysis of three socialist publications, over a 30 year period, tracks the level and nature of sports-themed coverage. The empirical material is then used to inform a discussion between those who reject sport and those who seek to reform it. With interest in the relationship between capitalism and sport continuing to attract academic attention (see 
Boykoff, 2013; Collins, 2013; Lavalette, 2013), this paper identifies an organisation that has, unapologetically, consistently focused on the politics of class and, resisting the turn to culture,

postmodernism or identity politics, remained firmly within the tradition of class-based, revolutionary Marxism. It begins with an assessment of the academic and popular literature representing the different leftist positions towards sport. The British Socialist Workers Party (SWP) is then located on the political spectrum before identifying the data sources and methods used. A series of vignettes are then presented, based around specific sporting events, to identify the contradiction that sport presents to those on the revolutionary left.

\section{The left and sport}

Prominent figures on the revolutionary left such as Marx, Luxemburg and Gramsci, were neither sports-lovers nor very physically active due, in part, to their poor health (Frolich, 1994; McLellan, 2006; Simon, 1982; Wheen, 2000). ${ }^{1}$ Lenin differed in that he enjoyed being physically active and was a keen sportsman (Elwood, 2010; Giulianotti, 2005; Lockhart, 1960; Riordan, 1991), and recognised its potential benefits, young people especially need to have a zest for living and be in good spirits.

Healthy sport - gymnastics, swimming, hiking, all manner of physical exercise - should be combined as much as possible with a variety of intellectual interests, study, analysis and investigation ... A healthy mind in a healthy body! (Lenin, cited in Riordan, 1996: 49)

Another significant figure on the revolutionary left is Trotsky who, in writing about the problems of everyday life, rarely mentioned physical activity, games or sport. The closest he came to 'sport' was in discussion of play in relation to education:

The character of the child is revealed and formed in its play. The character of an adult is clearly manifested in his play and amusements... The longing for amusement, distraction, sightseeing and laughter is the most legitimate desire of human nature. We are able, and indeed obliged, to give the satisfaction of this desire a higher artistic quality, at the same time making amusement a weapon of collective education. (Trotsky, 1994: 32)

As modern sport began to coalesce within Western industrial capitalist societies and grew in popularity at the beginning of the twentieth century, Trotsky recognised the role played by sport and the challenge it presented to socialist organisations:

The revolution will inevitably awaken in the English working class the most unusual passions, which have been hitherto been so artificially held down and turned aside, with the aid of social training, the church, the press, in the artificial channels of boxing, football, racing and other sports. (Trotsky, 1974: 123)

Many of the leading figures on the revolutionary left, including Lenin and Trotsky, were writing before sport formed a joint venture with the media and sponsors to achieve its current global position (Jhally, 1984, 1989; Lipsky, 1979; Rowe, 2004; Wenner, 1998). 
Many on the left have drawn inspiration from the Worker Sports movements of the late nineteenth and early twentieth century. During this period, Europe saw the emergence of workers societies which offered organised opportunities for hiking, cycling, swimming and gymnastics (Gechtman, 1999; Steinberg, 1978; Wheeler, 1978). The intention was to improve the quality of workers' leisure by removing class barriers to participation, offer alternatives to the bourgeois values celebrated in competitive sport and attract people to socialist ideas (Kruger and Riordan, 1996). As Jones (1992: 94) notes, sport was not seen as 'an end in itself, but as a means of fitting the workers with the necessary energy and stamina to face up to the class struggle of today, and the greater ones of the future'.

Different political allegiances informed the development of the two labour sports organisations. The Red Sport International (RSI) ${ }^{2}$ was located in the tradition of revolutionary Communism, whilst the much larger Lucerne Sport International (LSI) represented the social democratic version of socialism promoted by the reformist Labour movement (Riordan, 1996). Workers' Olympiads were organised to counter the emerging nationalism evident within the modern Olympic movement. First held in Prague (1921) and then in Austria (1931) these Olympiads were seen as high-points of the workers' sports movement, despite the exclusion of the Communist RSI, who organised their own competitions in Moscow (1928) and Berlin (1931) (Nitsch, 1996). Seeking to counter the rise of fascism (manifest in the 'bourgeois' 1936 Olympic Games), the Workers Olympiad planned for Barcelona in 1936 was cancelled because of the outbreak of the Spanish Civil War. Responding to the rise of fascism in Europe, the two movements subsequently worked together in a popular front to participate in the final Olympiad in Antwerp in 1937.

Academic and popular writing on sport has tended to reflect the distinction between those who see potential within sport and therefore something worth (re)claiming, and those who adopt a reductive and negative view of sport. Much of the Marxist writings on sport from the 1970s adopted a materialist approach, informed by political economy, with sport seen as an 'empty vessel' imbued with the dominant values of capitalism. Labour theory was used to explain the function of sport in reproducing labour ('re-creation', training and preparation for work). Rigauer (1981) focused on the division of labour with the athlete as producer (selling their labour power) and spectator as the consumer, Beamish (1982) highlighted class relations and the political economy of sport, whilst Hoch (1972) and Brohm (1978) offered Marxist polemics on sport and class divisions, racism and imperialism. Viewed by many on the left as compensation for alienating work, sport was viewed in the same light as Marx's view of religion.

Western Marxism emerged as a response to Stalinism, the events of 1956 and the failure of the working class to revolt. Orthodox Marxism was criticised for its crude economism (Hargreaves, 1994), and the focus shifted away from the 'industrial working class' to 'the masses' and their transformation from active citizens into passive consumers. Much of the blame for the 'massification of society' was levelled at the mass media, consumption and popular entertainment, including sport. Critical of sport (as part of mass culture), and taking inspiration from those identified with the 
Frankfurt School, the study of sport took a pessimistic turn wherein both the masses and sport contributed to the mass spectacle. Adorno was one of those who, although initially viewing sport as ambiguous and claiming to recognise the complexities of class relations, ultimately viewed sport as impeding intellectual development and presenting a pre-packaged consumable that led to 'pseudo individualisation' and 'unfreedom' (Inglis, 2004). Texts by Tomlinson and Whannel (1994) and Whannel (1983) sought to offer a more nuanced critique of sport not evident in previous Marxistthemed studies of sport, with the recent collection edited by Carrington and McDonald (2009) seeking to address the dynamic tension(s) between sport, culture, cultural studies and Marxism.

Hegemonic theory has often been used to critique the development of sport, its commercialisation, its inherently corrupt(ing) nature and how the bourgeoisie use their cultural and material resources to secure their dominant position (Gruneau, 1983; Hargreaves, 1986). Like all social practices, sport is a social construct and, as Sugden (2005: 251) notes, is 'neither essentially good nor bad ... its role and function depend largely on what we make of it and how it is consumed'. As an activity that both creates and reproduces the dominant values of society, it is thus a site for class contestation.

According to Morgan (1994), those who argue that sport cannot be extracted from its social context means that sporting practices are essentially 'empty vessels'. This position denies the possibility of sport being seen in any other way and limits critics from offering possible alternatives. For Morgan (1994: 157) this means 'that whatever the process of institutionalisation inscribes in the blank tablets of sporting practices literally defines those practices and so cannot be said to violate or undermine them in any meaningful sense'. The orthodox Marxist approach to sport was seen by Morgan (1994) as offering a particularly pessimistic prognosis, with its fate set to remain as a site for the production and reproduction of dominant capitalist values, something described as 'left functionalism'. A contrasting position was offered, premised on the condition that social practices are defined by the social reality in which they exist. If they exist in a capitalist society characterised by commercial values, then sport is just another site in which these values are (re)produced. For Morgan this approach undermines the ability to deliver change and instead he advocates for renewed, socially-conscious, liberalism by adopting a Habermasian-informed 'model for a democratic enlightened "practice community" for sport's reform' (Giulianotti, 2005: 61).

Tensions between those seeking to reform sport and those rejecting it can also be found in the popular literature produced and read by those outside academia. ${ }^{3}$ Many will be familiar with the Trotskyist, CLR James, and his seminal work on cricket (James, 1963/2005). James was a leading activist in British Trotskyism in the 1930s, meeting Trotsky (in Mexico) to discuss tactics on how to counter the endemic systematic racism in the US (Hogsbjerg, 2006). James's commitment to Trotskyism made him highly critical of Stalinism and Western Marxism, the latter of which he saw as elitist, inconsistent and incapable of dealing with the complexity of 'mass culture' (Grimshaw, 1992; Renton, 2007). Similar to Gramsci, James has often been depoliticised and presented as a cultural commentator, when in reality both were dedicated revolutionaries, implacable in their opposition to capitalism, fascism and imperialism. Marqusee $(1994,1999)$ as a fellow traveller of the revolutionary left (albeit one advocating parliamentary socialism), also saw beauty within sport, specifically cricket, and its potential to offer insight into wider social and political conditions. 
Celebrating sport, whilst cognisant of its current structure, Zirin has consistently argued for the possibilities sport offers to the political left. Zirin's work $(2005,2008,2010,2013)$ focuses on US sport and, although identifying himself with the left, he has been critical of the lack of engagement amongst socialists in sports (see King, 2008). Kuhn (2011) adopts a similar approach to Zirin in recognising the damage caused by capitalism, but also in identifying the potential that sport offers in bringing about progressive social change. Advocating a blend of leftist politics in the anarchist tradition, Kuhn's collection of articles, essays and interviews identifies many problems within soccer (e.g. nationalism, fan violence, exploitation of African players). However, Kuhn also identifies a number of emerging trends (e.g. egalitarian, 'DIY' lifestyles), with localised (grass-roots) activities offering alternatives to the current dominant capitalist model within sport (football) and within wider society. The approach adopted by Zirin and Kuhn in their populist writings illustrates one side of the debate, specifically the potential of sport, as opposed to those who see it as fundamentally counter-revolutionary.

In direct contrast to Zirin and Kuhn, Pearlman (2012) offers a Marxist polemic in which sport has no redeeming features. An outsider to sport, Pearlman argues that global capitalism uses sport to flatten everything its path. ${ }^{4} \mathrm{He}$ describes sport as a plague; it exists only because of globalisation, mass media and the need for commodified leisure time entertainment. Drawing upon Freud, Marx and the Frankfurt School (and Adorno's work in particular), he is theoretically located in the mechanical Althusserianism tradition with Brohms' ' 20 theses' ${ }^{5}$ re-presented along with the assertion that sport de-intellectualises and diverts the workers from the revolutionary struggle. Mass culture in general, and sport in particular, are seen to disguise the true condition of the working class with young people coming in for particular condemnation. Pearlman abhors sport for the same reason Marx disliked religion. However, Marx did show an understanding of why people might seek haven in a heartless world; Pearlman has no time for such tolerance. Concluding that sport is utterly worthless, impossible to reform or reclaim, he fails to countenance that mass culture might be 'bottom-up' with 'the masses' enjoying sport and/or using it to alleviate some of the ills created by capitalism.

This section has outlined the debate on the left between those who abhor sport and those who take a more ambiguous approach and seek to move beyond the dualism that 'sport is good/sport is bad'. After offering some background to the largest party on the revolutionary left in Britain, an empirical informed assessment will be presented on how this debate is being played out.

\section{The SWP}

1956 was a watershed for socialists. The Soviet Union's invasion of Hungary, the Suez Crisis and Khrushchev's 'secret speech' led many socialists to reflect on the established order and whether the working class continued to be the vanguard of revolutionary change. After 1956, whilst some socialists remained in groups linked to the official Soviet Communist Party, many others left 'the 
party' to set up alternatives to the centralised, totalitarian politics of Stalinism. The origins of the SWP lay in this exodus, with individuals initially joining the Revolutionary Communist Party (RCP), then the Socialist Review Group (SRG) and, more recently, the International Socialists (IS). As a group of British Trotskyists they sought to highlight what they saw as the 'bureaucratic state capitalist' nature of Stalinist Russia and create a political space for international socialism that supported 'neither Washington nor Moscow' (Birchall, 2011; Cliff and Gluckstein, 1988; Foot, 1993).

The SWP is a British-based revolutionary party dedicated to the overthrow of capitalism. It argues that the system and its structures (e.g. parliament, army, police and judiciary) cannot be reformed or taken over and used to the benefit of working people. It sees itself as a vanguard party of the working class and, via working class self-emancipation, seeks to build towards a revolution. Although parliamentary elections are a tactic used to 'agitate for improvements' and 'expose the system', in contrast to parliamentary socialism and other reformist groups (e.g. social democratic and 'green' parties), they argue that parliament will never challenge capitalism. Drawing heavily upon the ideas of Marx, Engels, Lenin, Luxemburg and Trotsky, key differences exist with those revolutionary left groups who look to Stalin or Mao's interpretations of Marxism. Much of the difference is based around Trotsky's writings on the USSR as a 'state capitalist' economy (rather than a degenerated workers state), the permanent revolution, the arms economy, an international working class and the dictatorship of the proletariat in bringing about a socialist revolution (Cliff, 1986, 1999, 2000).

The SWP adopts a democratic centralist approach with the self-activity of the working class at its core. Activists are encouraged to get involved in weekly meetings, paper sales and intervene in local campaigns. Although working with(in) trade unions, they are critical of the role of unions in mediating (read 'compromising') between workers and capitalists; the preferred tactic is building 'rank and file movements' to challenge the union bureaucracy. As a Trotskyist organisation, it advocates united front activity such as the Anti-Nazi League, set up to confront the rise of fascist activity in the UK in the 1970s (Goodyer, 2003; Renton, 2006) and recently remerging to counter the growing Islamophobia in the UK, as well united front activity around unemployment and war (Phillips, 2008; Reitan, 2009). Recent debates amongst those seeking to challenge capitalism have centred on the role of the political party, of structured and democratic accountability as opposed to an individualistic, autonomist approach preferred by those identifying with new social movements/moments (Calhoun, 2013; Chomsky, 2012; Gitlin, 2013; Hardt and Negri, 2000). Commonly seen in town centres, at industrial sites, picket lines and demonstrations, the SWP has been the most active and visible group on the revolutionary left in Britain. It is not possible to secure a precise figure for membership (with estimates of between 5000 and 10,000 ) ${ }^{6}$, but it has been seen to consistently 'punch above its weight' (Jones, 2013).

The Socialist Worker (SW) is the weekly newspaper of the SWP and has been published continuously since the late 1960s. Currently averaging 16 pages per edition and costing $£ 1.00$, sales in town centres and workplaces and through subscription are estimated to be around 8000 per week. Priced at $f 3.00$, the Socialist Review $(S R)$ is the sister magazine to the $S W$ and typically contains 30 pages. 
Published monthly since 1978, it has appeared over 350 times. The International Socialism journal (ISJ) first appeared in 1958 and currently appears quarterly. Typically containing eight in-depth articles across its 250 pages, its format and content is similar to a traditional academic journal. These three publications are central to the SWP's organisation and are used to promote socialist discussion and to establish and maintain political contacts. For Lenin, a socialist newspaper,

is not only a collective propagandist and a collective agitator, it is also a collective organiser. In this respect, it may be compared to the scaffolding erected round a building under construction. The organisation which forms around this newspaper will be ready for everything. (cited in Socialist Worker, 2010a).

Trotsky (2000: 157) also stressed the important role played by a socialist newspaper, a newspaper does not have the right not to be interested in what the masses, the people in the street, are interested in. Of course, our newspaper can and must throw light on facts, since it is called upon to educate, elevate, develop. The three selected SWP publications, whilst giving priority to the class struggle, also cover a range of leisure and cultural activities including music, theatre, literature, art exhibitions and television. These activities are also discussed at the annual conference of the SWP (see www.marxismfestival.org.uk). However, since the early 1990s only one meeting at this event has specifically addressed sport. That meeting began with the speaker castigating socialists who wore Brazilian football shirts and suggested they should familiarise themselves with the influence of Nike on team selection and the endemic racism within the country.

\section{Method}

The aim of this research was to undertake content, thematic and discourse analysis of three SWP publications: its weekly paper, monthly magazine and quarterly journal. Stemple (1981: 119) explains that content analysis is 'a formal system for doing something that we all do informally rather frequently' with various techniques available to the researcher (David and Sutton, 2011; Silverman, 2003). Previous content and discourse analyses of media coverage have identified their role in agenda-setting (Blain, 2003; Wanta, 2008), with quantitative and qualitative approaches showing gender and racial biases in media coverage (Bishop, 2007; Kian et al., 2009; King, 2007; Mackay, 2012; Messner et al., 2000; Millward, 2008; Vincent, 2004; Vincent et al., 2002, 2010).

A content analysis was undertaken to identify the number of articles which featured sport. A critical discourse analysis (Fairclough, 2003) was then employed as an unobtrusive and non-reactive method to structure the following discussion. A variety of search terms were used to identify sports-related articles, with the articles located via the SWP website or from personal contacts. After identifying the units to be sampled, specifically the weekly $S W$, the monthly $S R$ and the quarterly $I S J$, selection of the unit was on the criterion that the primary focus of the article was sport. The date, title and focus of each item was entered into a data processing package. Items were then coded for the sport, event and dominant theme(s). All the searching, coding and interpretation was undertaken by the author. The intention was to explore the level and nature of coverage of sport and offer a 
theoretically informed commentary on how the political orientation of the SWP, as a leading, contemporary, revolutionary socialist party informs its view of sport.

133 items appeared in the SW weekly paper (between 1999 and November 2012).

37 items appeared in the SR monthly magazine (between 1978 and November 2012).

2 items appeared in the ISJ quarterly journal (between 1978 and November 2012).

\section{Findings and discussion}

The earliest identified sport-themed article appeared in the $S R$ magazine which questioned the purpose of the Moscow 1980 Olympic Games. ${ }^{7}$ A second article published in 1984 was also critical of the Olympic Games being held that year. Three short articles on football appeared in the late 1980s and 1990s which focused on the negative influence of satellite television and the creation of the Premier League. Since 1999, the cultural page of the weekly SW newspaper has carried nine sports books and three sports film reviews. The books reviewed included Marqusee $(1994,1999)$ on cricket and Muhammad Ali, African football and colonialism (Hawkley, 2010), Italian football (Foot, 2007), Jesse Owens and Joe Louis (McRae, 2003), and sports in the USA (Zirin, 2008). Three films were briefly reviewed: Million Dollar Baby, Invictus and Fire in Babylon. The SR magazine, which typically carries between five and 10 book reviews each month, has featured just two sports books, both of which were overtly political (Allison, 1986; Brohm, 1978). The ISJ carried a single sports book review, namely Collins (2006) history of rugby league, with the reviewer concentrating on the class origins of the sport. One recognises the constraints on the space within these publications, and the primary focus given to class and industrial struggles; however, all these publications carry regular reviews of a range of cultural activities (e.g. music, theatre, literature, art exhibitions, television) but very little sport. Coverage was usually orientated around major sporting events, with many of the lead articles generating letters from readers taking issue with the content of the original article.

\section{'Stack on the Back'}

Between 1988 and 1994, the monthly SR featured sport 12 times. Typically, it was within a column that offered an irreverent, personal approach to topical events within popular culture. Pat Stack's first column featuring sport ('Stack on the Back') began by stating how 'a few years ago a common feature of SWP events (...) was a fairly jokey debate about whether we would have sport in a socialist society' and that, as a sports fan, he would 'line up with the pro-sport faction' (Stack, 1988b). Stack claims he had not given these debates much thought until a cricket tour of Pakistan in 1987 generated accusations of racism and chauvinism. Stack employs ironic humour to list various racist attributes and stereotypes accorded to 'the former colonies' before concluding that cricket was riddled with racism, patriotism, chauvinism and cheating. Noting that sport acted as an important escape from everyday life, Stack hoped sport would exist in a future socialist society but, until then, capitalism would continue to take 'even the apparently most harmless aspects of our daily lives and turn them into something disgusting, degrading and distorted'. 
Later that year, Stack (1988a) discussed the situation of South African runner, Zola Budd, obtaining a British passport and the contradictory position of politicians who sought to separate sport from politics and then, Janus-faced, put political issues before sport, citing the Olympic Games in 1980 and 1984. Stack (1988c) subsequently focused on football hooliganism and its links with right wing nationalism, revisiting the theme (Stack, 1989) in a discussion of football before the introduction of all-seater stadia, concluding that the 'hooligan problem' was largely a creation of media frenzy. In 1991, Stack returned to cricket and the class-based pomposity of its governing bodies. However, this particular column drew one reader to point out two factual errors within the column before adding that class bias also operated in the selection of the Pakistani national team (Abid, 1991). In 1993, Stack identified himself as a Tottenham Hotspur Football Club fan before complaining about the attempts to remove their manager and how football was increasingly governed by 'the bottom line' (Stack, 1993). A number of high profile deaths of sportsmen led Stack (1994) to challenge the notion that sport was healthy and character forming and he argued that sport was a product of the capitalist society, acknowledging that, very occasionally, it also challenged existing structures, citing the example of Muhammad Ali's position on Vietnam and civil rights.

Over a seven-year period, Stack wrote more than 50 monthly columns, of which seven discussed sport, and his was the main site for sport in the three SWP publications. During this period, the three publications contained regular features celebrating other leisure activities ranging from television programming, art exhibitions, cinema, theatre and opera reviews, dance, drama and beyond - but rarely sport. What is evident is that sport was viewed as significantly different from these activities, despite being part of the entertainment industry.

\section{UEFA European Championship}

The ISJ is the main theoretical publication of the SWP and out of 239 issues it has featured sport twice; the first time during the UEFA European Championship tournament when England was the host nation (Bambery, 1996). ${ }^{8}$ The article begins by recognising the popularity of sport before moving to discuss the link between sport and capitalism and the revenues generated by the large corporations (e.g. Nike, NFL and English Premier League). Bambery claims that people are interested in sport because of the alienating effects of work under capitalism and that sport should be seen as an 'unfree' activity; ultimately sport is seen as a misguided, if understandable, attempt to escape from the drudgery of life under capitalism. Moving beyond sport to consider leisure under capitalism, he employs Bravermen's theory of alienation to suggest that leisure is shaped by work and is similarly alienating, with identification of how the human body suffers under capitalism and the pressures placed upon individuals to conform to the 'right shape'. Bambery then criticises the notion of sport as meritocratic and highlights the demands of top level sport, citing Ryan's (1996) Pretty Girls in Little Boxes, before moving on to discuss the historical links between sport and warfare. 
The regulation and codification of modern sport is linked to the rise of modern industrial capitalism with football located within class-based, muscular Christianity which, via imperialism, was exported throughout the British Empire. Contemporary football is seen to mirror wider social/industrial relations in terms of discipline, hierarchy and specialisation, with John Hargreaves cited to support the claim that sport is an expression, 'in a concentrated form [of] bourgeois ideology (aggressive individualism, ruthless competition, elitism, chauvinism, sexism and racism) and that its bureaucratic administration is linked closely to the capitalist state' (Bambery, 1996: 47). Similarly, the modern Olympic Games and FIFA's World Cup finals are seen as,

totally integrated into a framework of inter-state rivalry, capitalist production and class relations. As an ideology, transmitted on a huge scale by the media, it is part and parcel of ruling bourgeois ideology. The hierarchical structure of sport reflects the social structure of capitalism and its system of competitive selection, promotion, hierarchy and social advancement. The driving forces in sport performance, competitiveness, records are mirrors of the driving forces of capitalist production. (Bambery, 1996: 47)

Brief reference is made to how sport has been used for political protest, citing the examples of the 1968 'Black Power Salute', Muhammad Ali's statements and the Anti-Nazi League's (ANL's) use of sporting personalities to promote anti-racism. However, Bambery cautions that 'we should be careful about exaggerating the general importance of these examples'. Bambery echoes the ideas of Lenin and Trotsky that socialists should 'rescue the element of play in leisure' and that 'under socialism there will be physical recreation but not sport', and that socialism rests in the idea that humans are co-operative, not competitive,

Socialism will not be a society in which 30,000 people watch 22 kick a football - nor swim up and down lanes - it will be about physical recreation and play - about the enjoyment of one's body, human company and the environment. (Bambery, 1996: 51)

He concludes that 'socialists understand why people take part in or watch sport - it being an escape from the harsh world in which we live. That is why we do not ignore sport' (1996: 52). Bambery argues that socialists 'should follow the example of the Bolsheviks and pull out of all sports competition based on nationalism. Our aim is human liberation [...] a world in which future generations will look back in wonder at [...] the Olympics and ask only one question "Why?"'. Throughout his article, Bambery adopts a primarily orthodox Marxist theory to view sport.

\section{FIFA World Cup}

On the eve of the 2002 FIFA World Cup Finals, three related articles appeared in the SW. In the first, Molyneux (2002) questioned why sport meant so much to so many working people; his answer 'was both simple and obvious ... capitalism ensures that for most people work is monotonous, stressful, exhausting and damaging to the mind and body; thus sport offers real time drama with moments of excitement and passion'. Noting the collective community element with most sports, Molyneux highlighted that this was often reactionary and included displays of racism, nationalism and class collaboration. However, he concluded by stating that as socialists 'we have no desire to isolate our- 
selves by being killjoys or spoilsports, but it does help if we understand what we are dealing with' (Molyneux, 2002).

Cardwell's (2002) article begins with the well-rehearsed quotation from Orwell on sport, followed by a list of Olympic Games that had an overt political dimension. A litany is then made on why sport is 'bad', including Norman Tebbitt's 'cricket test' and the existence of drugs in sport. ${ }^{9}$ Briefly noting the organisation of 'sport' before industrial capitalism, little within contemporary sport was seen as worth celebrating. In the third article, Gonzalez (2002) questions whether watching sport can ever be a simple, enjoyable and harmless activity. Noting that nationalism was not limited to the English, Gonzalez does not want an 'attack on the beautiful game. But sport, like every other cultural activity, is a contradictory space where there is a struggle for appropriation. Sometimes, our side can take it back.' Pausing to celebrate the success of West Indies cricket in challenging racism, Gonzalez (2002) condemns French football clubs for exploiting North African youth and criticises FIFA and the IOC for their corruption and misuse of power, before suggesting there was 'still beauty ... excitement and suspense ... in the game'. He concludes by asking (but not answering) whether it is 'possible to love the beautiful game - the skill, the fluidity, the athleticism - without carrying the flags?' A letter published the following week from Margulies (2002) responded by claiming that the success of Turkish national team in the recent World Cup had led to increased nationalistic and fascist activity within her country, concluding that 'nobody on the political right or left, should think for a moment that football was just a game or that waving the flag was just a bit of harmless exuberance'.

What the three articles recognise, but only briefly attempt to explain, is the popularity of sport. The popularity of sport is seen as a result of the alienation created by capitalism; however, this onedimensional explanation is not discussed at any length. The negative framing of sport leaves little space for the prospect of sport being used as a site for political activity and/or simply enjoying it. Sport is viewed solely in terms of passive consumption with its recreational, playful, participatory elements neglected. Only one letter in support of the original articles was published; it might be that no other letters were received, or perhaps readers did not feel comfortable in celebrating sport. The SWP prioritises the consciousness of the working class and seeks to respond to issues that matter to the class. However, interpreting support for national teams as nationalistic, right-wing (with xenophobic tendencies) risks neglecting 'where the class is' and locating all working class sports fans within the lumpenproletariat.

\section{'Stack on the Back' (Part II)}

In 2002, Stack discussed his excitement at the forthcoming football season. After highlighting the growing gulf between the Premier League and the lower division, Stack (2002) suggested that clubs going bankrupt would please many on the left. After noting the ability of capitalism to alienate and atomise individuals, he suggested it was 'better to waste an evening at the Valley (home to Charlton Athletic FC) than waste a life in a crack house'. In a letter published the following week, Rose (2002) criticised Stack's interest in football, stating that, given its racist chanting, hooliganism, money 
grabbing directors and prima-donna players, socialists should be willing the demise of football. However, a subsequent letter from Drake (2002) stated that he was pleased that Stack "ccame out" as a footie fan, so making me feel less like a heretic'. Drake stated his disappointment that Rose (2002) chose to cite the usual 'charge-sheet' of racism, violence, hyper-masculinity and commercialism, and questioned why football is the focus for criticism when all sports suffer from these traits - albeit to different levels. Drake (2002) concluded by suggesting that 'for many of us, football is joyful, inspiring and uplifting. No amount of tutting or rational arguments will squash these feelings. Surely socialist football fans shouldn't be shamefacedly hiding our enthusiasm, but rather engaging in the struggle for the soul of the game'. What is notable is how Drake sees himself as a 'heretic' by challenging those who see 'sport as bad' and for suggesting a socialist need to engage in sport. However, what Drake see as 'the "soul" of the game' is not clear.

\section{England vs. Australia (Ashes Test Series)}

The success of the English cricket team against Australia in 2005 created a brief flurry of interest in sport in the SWP publications. Writing in the $S R$, Stone (2005) identifies himself as a cricket lover, before presenting a list of what is wrong with the sport: the commercial deals secured by the Australian players; South African-born Kevin Pieterson's decision to play for England; the D'Oliveira affair; $^{10}$ the Tebbitt test; the 'rebel tour' to South Africa during the apartheid era; David Frith's questioning of black players' commitment when playing for England; and the lack of facilities at grass-roots, especially in the inner cities. Stone (2005) concludes by suggesting that,

it might seem wilfully perverse ... for socialists to turn up our noses at the wave of sporting patriotism, to take an 'anyone but England' line. Surely there are enough ideological battles for us to fight without provoking another around something as trivial as a bat and ball game?

Responding in a letter, Grant (2005) suggests that Stone neglects to mention the drama of sport in favour of 'hackish apartheid-era sound bites'. Instead of focusing on Pieterson and selection issues, Grant (2005) contends Stone should have focused on the 'gay-baiting' Pieterson received from some fans, and that the Test series was about 'glory, respect, camaraderie and fun ... there was so much to enjoy, and even more to laugh and chat about. But I wonder if all that is a sin in Andrew's world? I doubt it. So why couldn't he express it?' What remains absent is discussion on why so many working class people identify with sport and the various political, social and physical benefits that might be gained from being involved in sport.

\section{Summer Olympic Games}

The 2008 Beijing Olympic Games received significant attention. Coverage began with an editorial (Socialist Worker, 2008b) which focused on how competition in sport mirrored wider capitalist relations and how there was 'little or no enjoyment amongst those taking part in events such as the Olympics, the World Cup or the Tour De France'. A second editorial (Socialist Worker, 2008a) commented on the financial costs associated with medal success for Team GB and the siphoning of National Lottery funds away from community schemes. Bambery (2008) acknowledged that sport offered an escape from the realities of everyday life but complained how the modern Olympic 
Games had become a 'corporate orgy'. In a section on sport and physical activity, Bambery (2008) describes how:

Physical activity has become detached from play and enjoyment. In a world in which we controlled our lives and were at one with our environment we would enjoy swimming in the sea or trekking in the mountains as much as reading a book, helping construct a home or growing plants. Physical activity would become liberated from the constraints of competition. Physical recreation and play are about the enjoyment of one's body, human company and the environment. Sport is not.

This prompted a letter from Drake (2008) which criticised Bambery's position. Although, under the current system, Drake suggested there was a constant attempt to colonise individuals' leisure time,

to declare that human emancipation will see the end of all desire to compete seems to me to be throwing the sporting baby out with the capitalist bathwater. Will a socialist revolution really see us lose all interest in watching footie or playing chess?

Drake (2008) highlights the unknown promise of a future socialist society and, implicitly, how the weight of past generations will exert a sustained influence before a truly socialist society will shake off the chains of history. Discussion of sport under capitalism often minimises its positive, empowering enriching elements. There is no discussion on differences between team and individual sports, nor whether some sports are more socialist than others.

In an article that discussed the relationship between the Chinese and the USA economies, Callinicos (2008) began by stating that he found, 'the Olympics irritating at the best of times. Two weeks of corporate-sponsored flag-waving in honour of a bunch of muscle-bound dullards is not my cup of tea.' This apparent 'off-the-cuff' statement drew a series of letters which rebuked this position. Evans (2008: 7) pointed to the inspirational examples of female competitors running in the hijab and the challenge to the system made by Jesse Owens and Muhammad Ali, concluding that 'to dismiss [sport] as something "irritating" sounds patronising and elitist and makes socialists sound out of touch'. Blair (2008: 7) highlighted how some 'Socialist Worker writers seem to have extreme criticism of popular sport' and suggested Callinicos' statement was little more than vulgar mechanical Marxism. Citing US Marxist agitator JP Cannon as an accomplished sports commentator, Blair (2008: 7) suggested: 'He could make serious criticism of capitalism's domination of our dreams while drawing socialist lessons from top boxing, baseball and football.' Continuing the rebuke, Knobloch (2008: 7) failed to see how Olympic 'bashing' was helpful, whilst Scott (2008: 7) concluded the quartet of readers' letters by suggesting that 'loving sport proves that Marxists have contradictory consciousness' and argued for a better understanding of the ideological purposes of sport under capitalism. It is the readers who sought to extend the debate and identify how sport does not simply reproduce existing power relations but that it might be used to challenge dominant racial and gendered ideologies.

\section{FIFA World Cup}

Shortly before the 2010 FIFA World Cup, the SW carried a double-page feature on what hosting the World Cup would mean to 'ordinary' South Africans. It focused on the forced removal of people from 
stadium sites, a lack of water and electricity, police harassment, workers striking to win better pay, FIFA's clampdown on unofficial street vendors and the negative environmental impact of hosting the event. During the competition, a single sports-related article appeared under the heading 'Not flying the flag for England in the World Cup' (Socialist Worker, 2010b). It identified how the mainstream media sought to promote an image of a united sporting nation, and claimed that many people were uninterested in the event, with some of them feeling intimidated by the appearance of the Cross of St George flag given its historical association with imperialism, violence and racism. The mainstream media's focus on sporting patriotism and national unity involved a denial of class relations and an increased tendency to blame migrants for society's ills.

In response, Fanning (2010) argued that such analysis was overly simplified and noted that incorrect statements made in the original article 'risk[ed] disarming socialists in tough arguments'. Instead, Fanning argued that sport was not intended to divide but to bring people together, and that many international events were established by idealists seeking to promote international goodwill, 'only to see their ideals destroyed by the iron law of capitalist appropriation'. Fanning's position was subsequently criticised by Jones (2010) who suggested there was little to be gained in trying 'to reconcile oppressed nations to their imperialist master'. Citing de Coubertain's motives in establishing a modern Olympics, Jones (2010) concluded that international sport was always intended to promote individual nations and that whilst 'socialists can and do enjoy sport ... we should not be blind to the history and ideology that underpins it'.

\section{London 2012}

Unsurprisingly, there was significant coverage when London hosted the Olympic and Paralympic Games. Four themes dominated the coverage: a threatened strike by bus drivers; militarization and security; commercialisation; and the Paralympic Games sponsors. Before the Games the SW paper carried a steady stream of reports which tracked a strike threat by London bus drivers during the Games. A second theme, on the security and militarization of the Games, focused on the decision to place missile systems on the roofs of residential tower blocks. Demonstrations were called to protest against this decision as well as the temporary laws which allowed private security companies to use force against any protest or branding deemed offensive to the corporate sponsors (Slorach, 2012).

Throughout the SWP's coverage of London 2012 was criticism of the 'fat cat' sponsors. A doublepage feature, titled 'The Real Game is Profit' 'names and shames' 10 sponsors/contractors (e.g. Capita, Carillion) who were 'pocketing millions of pounds of government cash from the project' in contrast to the low pay of those in service roles, such as cleaners (Sewell, 2012). Also featured were the security firm, G4S and their contracts with the UK government to run six prisons and three immigration detention centres, in addition to private security in Afghanistan (Walker, 2012). A 'Flying the flag' editorial (Socialist Worker, 2012) reiterated previous discussion on this issue. However, this time it generated a letter from Nork (2012): 'Please don't be so negative - criticism of Britain's flag or the Olympic flame is absurd. Britain's flag is a symbol of unity. A travelling torch 
brings a bit of spirituality to the Olympics.' However, a letter from a football supporter claimed that they had recently been arrested for flying a flag which contained a starry plough, on the grounds that he was showing support for a prescribed terrorist organisation (Keenan, 2012).

Although much of the coverage was not on sport itself, but on wider issues, there was some focus on sport. SW carried a double-page feature on the workers' sports movement (Basketter, 2012). John Carlos' participation at an anti-racism event in London also featured along with articles exploring the Olympics as a site of struggle against racism (McCann, 2012; Olende, 2012; Richardson, 2012a, 2012b). The ISJ carried its second only article on sport, in which Dave Zirin was interviewed about the contradictory nature of the Olympic Games (Zirin and Edwards, 2012). At its annual Marxism event, ${ }^{11}$ which took place immediately prior to the Games, only one sports-themed meeting was scheduled, titled 'East London and the Olympics'. A number of local meetings were scheduled across the UK, whose titles included: 'The Olympics - sport for the 99 percent or profit for the 1 percent', 'The Olympics - big business and the politics of sport', 'Sport, power, money and the politics of the Olympics', 'The Olympics and the politics of sport' and 'What do we mean by the Olympic spirit?' Notably, during the Olympic Games there was no coverage of the event itself. The Paralympics generated renewed coverage with numerous reports on how disabled athletes were being lauded at the same time that the UK government were, via Games sponsor ATOS, making significant 'cuts' to the state support for disabled people. A number of local meetings were scheduled under the heading 'Paralympics, Atos and Remploy: the politics of disability'.

\section{Discussion}

This paper has focused on the debate between those on the revolutionary left and the new/cultural left, between those who reject sport and those who argue it has potential and is therefore worthy of reclamation and reform. The above discussion, based on empirical material, seeks to illustrate how one political group are engaged in the debate. What the above empirical data suggests is, that whilst the SWP do not have 'a position' on sport, much of the content and language of the SWP's reporting of sport is firmly rooted in its materialist, orthodox understanding of Marxism. There is a consistent focus on the negative aspects of sport rather than treating it sui generis or seeing it as a suitable site for socialist activity. Much of the coverage argues how the ideology of capitalism is used to legitimate sport and how sport acts to secure, reproduce and reinforce capitalist relations with a commodity spectacle. Theoretically, the most systematic discussion of sport was Bambery's (1996) article. It could be argued that the onus was then on socialists, with different interpretations of sport, to challenge Bambery's argument in subsequent publications; that no-one has (yet) done so suggests that it might be interpreted as the closest to a 'party line'. That said, a single article should not be seen as representing how sport is viewed by the SWP - but rather as contributing to the debate on the role of sport for the individual, contemporary and potential (future socialist) society. What is evident, often within letters generated by original articles, are those advocating a more dialectical approach to sport. Sport is often seen to lack the same revolutionary potential of avantgarde art, revolutionary cinema or literature (McDonald, 2009: 45) and is much less important than issues of war, poverty, racism, sexism and state oppression. This is perhaps why the SWP's coverage 
of sport does not dwell on sport per se, but instead highlights the link to wider structures and political economy.

Sport is not homogeneous and is part of the process in which structures of class domination are maintained and informed by patriarchy, sexism, homophobia and racism. In an attempt to understand the popularity of sport, the engagement of those on the new/cultural left seems to offer greater traction than the more orthodox versions of Marxism. Central to the traditional Marxist conception of ideology is the dialectic between the way in which people perceive the world as being socially determined and how their perception is distorted and ultimately false. The suggestion is that sport is contradictory in that it can be used to challenge capitalist exploitation and oppression, in particular racist and sexist behaviour, at the same time as being an activity that generates and reinforces values held in wider society. The focus of much of the coverage is that sport primarily serves the interests of capitalism, in part by entertaining, pacifying and disciplining the working class. There is little recognition that sport, like other cultural activities might also be empowering and used an activity to challenge the capitalist system. The reawakening of interest in class analysis and political economy suggests a need to engage in sport, develop an analysis and increase the relevance of socialist ideas.

Sport is competitive, and with capitalism based on competition, the debate has often become polarised. As to whether there would be sport in a future socialist society, it is impossible to know. Only when a communist society has shaken off all the muck of ages might it become possible offer such a statement. In the meantime, offering alternatives to the capitalist model of sport (as the mass participation Workers Olympiads sought to do), which would involve accepting sport as an activity for, and in, itself for all members of society, is one option. However, this proposal would face an intense set of circumstances in which neo-liberal capitalism seeks to destroy much of the social fabric and any sense of a collective working class consciousness.

Fundamental to Marxism is how oppression is located and, consequently, the strategies that are used to build towards liberation/emancipation. Based on the above, the SWP have only peripherally engaged with sport (as part of popular culture), and not offered a sustained assessment as to why people engage in sport. However, the problem for revolutionary socialists remains that sport primarily acts to support and promote the system rather than undermine dominant ideologies (McDonald, 2009: 43). Therefore, the leftist debate over sport, on whether to see it as a site for struggle, or engage in it or reject it as a plague, is fundamental. The SWP are rooted in the Marxist tradition in which praxis is central; people are born into circumstance not of their own choosing, and as human agents of the world in which they inhabit, they are the architects of change. Despite its current popularity, sport is principally seen as a stepping stone, but not as a key battleground.

\section{Conclusion}


This paper has focused on the representation of sport in three SWP publications. However, the SWP's engagement with sport goes much wider than this. Individual party members are involved in political activity linked to sport including campaigns against racism amongst football fans and campaigns to keep open local leisure centres and swimming pools. Future research might potentially identify how individuals on the far left understand their own sporting behaviour, their membership of a revolutionary party and their understanding of the reformist/rejectionist debate over sport. What this paper has sought to do is provide an empirically informed discussion on how one group on the revolutionary left are engaged in the debate over the role of sport and how this is a microcosm of the wider debate between those on the revolutionary and reformist left.

This paper has focused on a marginal, yet still significant, political group, to offer a broader understanding of leftist politics and sport. The empirically informed analysis has shown the existence of an orthodox Marxist position that views sport as too trivial a cultural phenomenon to take seriously. The dominant, but not only, conception of sport in the SWP's coverage can be seen as pessimistic in that it acts to limit the potential to build a united front movement, based around sport, to challenge capitalism. Communists accept that human nature is not fixed but determined by social conditions. That capitalism is seen as rooted in competition (and sport is competitive) does not necessarily make competitive sport 'bad'. 


\section{References}

Abid F (1991) Bowled out. Socialist Review, October, 146.

Allison L (ed.) (1986) The Politics of Sport. Manchester: Manchester University Press.

Bambery C (1996) Marxism and sport. International Socialism 73: 35-53.

Bambery C (2008) Sport's race to the bottom. Socialist Worker, 9 August, 13.

Basketter S (2012) A league of our own. Socialist Worker, 14 July, 14-15.

Beamish R (1982) The political economy of professional sport. In: Harvey J and Cantelon H (eds) Not Just a Game: Essays in Canadian Sport. Ottawa, ON, Canada: University of Ottawa Press, pp. 141158.

Birchall I (2011) Tony Cliff: A Marxist for His Time. London: Bookmarks.

Bishop R (2007) Missing in action: Feature coverage of women's sports in Sports Illustrated. Journal of Sport \& Social Issues 27(2): 184-194.

Blain N (2003) Beyond 'Media Culture': Sport as dispersed symbolic activity. In: Bernstein A and Blain N (eds) Sport, Media, Culture: Global and Local Dimensions. London: Cass, pp. 227-253.

Blair G (2008) You're wrong: Olympics can inspire socialists. Socialist Worker, 30 August, 7.

Boykoff J (2013) Celebration Capitalism and the Olympic Games. London: Routledge.

Brohm J-M (1978) Sport a Prison of Measured Time. London: Ink Links. 
Calhoun C (2013) Occupy Wall Street in perspective. British Journal of Sociology 64(1): 26-38.

Callinicos A (2008) Olympian hoo-hah over China power. Socialist Worker, 16 August. Available at: http://socialistworker.co.uk/art/15459/Olympian+hoo-hah+over+China+power

Cardwell J (2002) Sport: It's just not cricket. Socialist Review, July/August. Available at: http://www.socialistreview.org.uk/article.php?articlenumber=8066

Carrington B and McDonald I (eds) (2009) Marxism, Cultural Studies and Sport. London: Routledge.

Chomsky N (2012) Occupy. London: Penguin.

Cliff T (1986) State Capitalism in Russia. London: Bookmarks.

Cliff T (1999) Trotskyism after Trotsky: The Origins of the International Socialists. London: Bookmarks.

Cliff T (2000) A World to Win: Life of a Revolutionary. London: Bookmarks.

Cliff T and Gluckstein D (1988) The Labour Party: A Marxist History. London: Bookmarks.

Collins T (2006) Rugby's Great Split: Class, Culture and the Origins of Rugby League Football. Abingdon: Routledge.

Collins T (2013) Sport in Capitalist Society. London: Routledge

David M and Sutton C (2011) Social Research. 2nd ed. London: SAGE.

Drake B (2002) They think it's all over. Socialist Review, November. Available at: 
http://www.socialistreview.org.uk/article.php?articlenumber=8215

Drake B (2008) We'll have sport under socialism. Socialist Worker, 23 August, 7.

Elwood C (2010) The sporting life of V.I. Lenin. Canadian Slavonic Papers LII(1-2): 79-94.

Evans T (2008) You're wrong: Olympics can inspire socialists. Socialist Worker, 30 August , 7.

Fairclough N (2003) Analysing Discourse: Textual Analysis for Social Research. London: Routledge.

Fanning J (2010) Sport was not invented to divide. Socialist Worker, 17 July. Available at: http://www.socialistworker.co.uk/art/21391/Letters

Foot J (2007) Calcio: A History of Italian Football. London: Harper.

Foot P (1993) Why You Should Join the Socialists! London: Bookmarks.

Foot P (2000) Introduction. In: Cliff T (ed.) A World to Win: Life of a Revolutionary. London: Bookmarks, pp. xi-xvi.

Frolich P (1994) Rosa Luxemburg: Ideas in Action. London: Pluto Press/Bookmarks.

Gechtman R (1999) Socialist mass politics through sport: The Bund's Morgnshtern in Poland, 19261939. Journal of Sport History 26(2): 326-352.

Gitlin T (2013) Occupy's predicament: The moment and the prospects for the movement. British Journal of Sociology 64(1): 3-25.

Giulianotti R (2005) Sport: A Critical Sociology. London: Polity. 
Gonzalez M (2002) Ugly side of the beautiful game. Socialist Review, July/August. Available at: http://www.socialistreview.org.uk/article.php?articlenumber=8067

Goodyer I (2003) Rock against racism: Multiculturalism and political mobilization, 1976-81. Immigrants \& Minorities 22(1): 44-62.

Grant N (2005) A summer to celebrate. Socialist Review, October. Available at: http://www.socialistreview.org.uk/article.php?articlenumber=9553

Grimshaw A (ed.) (1992) The C.L.R. James Reader. Oxford: Blackwell.

Gruneau R (1983) Class, Sports and Social Development. Amherst, MA: University of Massachusetts Press.

Gumbrecht HU (2006) In Praise of Athletic Beauty. London: Harvard University Press.

Hardt M and Negri A (2000) Empire. London: Harvard University Press.

Hargreaves J (1986) Sport, Culture and Ideology. Cambridge: Polity.

Hargreaves J (1994) Sporting Females: Critical Issues in the History and Sociology of Women's Sport. London: Routledge.

Hawkley I (2010) Feet of the Chameleon: The Story of African Football. London: Portico.

Hoch P (1972) Rip Off the Big Game. New York: Doubleday.

Hogsbjerg C (2006) C.L.R. James: The revolutionary as artist. International Socialism 112, pp. $163-$ 182. 
Hunt T (2009) The Frock-Coated Communist: The Revolutionary Life of Friedrich Engels. London: Penguin.

Inglis D (2004) Theodor Adorno on sport: The jeu d'esprit of despair. In: Giulianotti R (ed.) Sport and Modern Social Theorists. Basingstoke: Palgrave Macmillan, pp. 81-96.

James CLR (1963/2005) Beyond a Boundary. London: Yellow Jersey Press.

Jhally S (1984) The spectacle of accumulation: Material and cultural factors in the evolution of the sports/media complex. Insurgent Sociologist 12: 43-57.

Jhally S (1989) The Spectacle of Accumulation: Essays in Culture, Media, \& Politics. New York: Lang.

Jones J (2010) Does sport really bring us closer? Socialist Worker, 24 July. Available at: http://www.socialistworker.co.uk/art/21455/Letters

Jones O (2013) British politics urgently needs a new force - A movement on the Left to counter capitalism's crisis. The Independent. Available at:

http://www.independent.co.uk/voices/comment/british-politics-urgently-needs-a-new-force--amovement-on-the-left-to-counter-capitalisms-crisis-8459099.html

Jones S (1992) Sport, Politics and the Working Class. Manchester: Manchester University Press.

Keenan J (2012) Charged for flying a flag. Socialist Worker, 2 June, 7.

Kian E, Mondello M and Vincent J (2009) ESPN - The women's sports network? A content analysis of Internet coverage of March madness. Journal of Broadcasting \& Electronic Media 53(3): 477-495.

King C (2007) A text and picture analysis of British National Newspaper Coverage of the Olympic Games since 1948. International Review for the Sociology of Sport 42(2): 187-199. 
King C (2008) Toward a radical sport journalism: An interview with Dave Zirin. Journal of Sport \& Social Issues 32(4): 333-344.

Knobloch B (2008) You're wrong: Olympics can inspire socialists. Socialist Worker, 30 August, 7.

Kruger A and Riordan J (eds) (1996) The Story of Worker Sport. Leeds: Human Kinetics.

Kuhn G (2011) Soccervs. the State: Tackling Football and Radical Politics. Oakland, CA: PM Press.

Lavalette M (2013) Capitalism and Sport: Politics, Protest, People and Play. London: Bookmarks.

Lipsky B (1979) Political implications of sports team symbolism. Politics and Society 9(1): 61-88.

Lockhart RB (1960) Giants Cast Long Shadows. London: Putnam.

McCann E (2012) Mexico 68: Massacre at the games. Socialist Worker, 26 May, 10-11.

McDonald I (2009) One-dimensional sport: Revolutionary Marxism and the critique of sport. In: Carrington B and McDonald I (eds) Marxism, Cultural Studies and Sport. London: Routledge, pp. 3247.

Mackay C (2012) "Back the Bid": The London Olympic Bid Committee and the Sun newspaper. Journal of Sport \& Social Issues 36(4): 410-421.

McLellan D (2006) Karl Marx: A Biography. 4th ed. London: Palgrave Macmillan.

McRae D (2003) In Black and White - Jesse Owens and Joe Louis. London: Simon \& Schuster. 
Margulies R (2002) The blood-soaked flag. Socialist Review, September. Available at:

http://www.socialistreview.org.uk/article.php?articlenumber=8132

Marqusee M (1994) Anyone but England: Cricket and the National Malaise. London: Verso.

Marqusee M (1999) Redemption Song: Muhammad Ali and the Spirit of the Sixties. London: Verso.

Messner M, Dunbar M and Hunt D (2000) The televised sports manhood formula. Journal of Sport \& Social Issues 24: 380-394.

Millward P (2008) Rivalries and racisms: 'Closed' and 'open' islamophobic dispositions amongst football supporters. Sociological Research Online 13(6): 5. Available at: http://www.socresonline.org.uk/13/6/5.html

Molyneux J (2002) Why is sport so popular? Socialist Worker, 29 June. Available at: http://www.socialistworker.co.uk/art/5242/Why+is+sport+so+popular\%3F

Morgan WJ (1994) Leftist Theories of Sport. Urbana, IL: University of Illinois Press.

Nitsch F (1996) The two international worker sport organisations: Socialist Worker Sports International and Red Sport International. In: Kruger A and Riordan J (eds) The Story of Worker Sport. Leeds: Human Kinetics, pp. 167-170.

Nork T (2012) Please don't be so negative. Socialist Worker, 2 June.

Olende K (2012) flame of revolt is still burning for John Carlos. Socialist Worker, 26 May, 9.

Pearlman M (2012) Barbaric Sport: A Global Plague. London: Verso.

Phillips R (2008) Standing together: The Muslim Association of Britain and the anti-war movement. Race \& Class 50(2): 101-113. 
Reitan R (2009) The global anti-war movement within and beyond the world social forum.

Globalizations 6(4): 509-523.

Renton D (2006) When We Touched the Sky: The Anti-Nazi League, 1977-1981. Cheltenham: New Clarion Press.

Renton D (2007) CLR James: Cricket's Philosopher King. London: Haus.

Richardson B (2012a) A nation united? Socialist Review, September, 22.

Richardson B (2012b) The politics of the Olympics. Socialist Review, May, 10-12.

Rigauer B (1981) Sport and Work. New York: Columbia University Press.

Riordan J (1991) Sport, Politics and Communism. Manchester: Manchester University Press.

Riordan J (1996) Worker sport within a worker state. The Soviet Union. In: Kruger A and Riordan J (eds) The Story of Worker Sport. Leeds: Human Kinetics, pp. 43-65.

Rose A (2002) Sick as a parrot. Socialist Review, October. Available at: http://www.socialistreview.org.uk/article.php?articlenumber $=8174$

Rowe D (2004) Sport, Culture and the Media: The Unholy Trinity. 2nd ed. Buckingham: Oxford University Press.

Ryan J (1996) Little Girls in Pretty Boxes. London: The Women's Press.

Scott A (2008) You're wrong: Olympics can inspire socialists. Socialist Worker, 30 August, 7. 
Sewell D (2012) The real game is profit. Socialist Worker, 17 March, 17-18.

Sibler I (2003) Press Box Red: The Story of Lester Rodney, the Communist Who Helped Break the Color Line in American Sports. Philadelphia, PA: Temple University Press.

Silverman D (2003) Interpreting Qualitative Data: Methods for Analysing Talk, Text and Interaction. 2nd ed. London: SAGE.

Simon R (1982) Gramsci's Political Thought: An Introduction. London: Lawrence \& Wishart.

Slorach R (2012) Cleansing and clampdown. Socialist Review, June, 8.

Socialist Worker (2008a) Olympics: Buying gold medals. Editorial. Socialist Worker, 23 August, 12.

Socialist Worker (2008b) Olympics: Competition in sport reflects capitalism. Editorial. Socialist Worker, 12 April. Available at: http://socialistworker.co.uk/art.php?id=14597

Socialist Worker (2010a) Do we still need a revolutionary paper? What socialists say. Socialist Worker Online, 17 August. Available at: http://www.socialistworker.co.uk/art.php?id=22147

Socialist Worker (2010b) Not flying the flag for England. What socialists say. Socialist Worker, 19 June. Available at: http://www.socialistworker.co.uk/art/21133/Not+flying+the+flag+for+England+in+the+World+Cup

Socialist Worker (2012) What socialists say: Is waving union jacks just harmless fun? Socialist Worker, 12 May, 11.

Stack P (1988a) Over the bottom line. Stack on the back. Socialist Review, June, 110. Available at: http://pubs.socialistreviewindex.org.uk/sr266/stack.htm 
Stack P (1988b) The umpire strikes back. Socialist Review, January, 105.

Stack P (1988c) What's my line? Stack on the back. Socialist Review, July/August, 111.

Stack P (1989) Putting the boot in. Stack on the back. Socialist Review, May, 120.

Stack P (1991) Coup, what a scorcher. Stack on the back. Socialist Review, September, 145.

Stack P (1993) Moving the goal posts. Stack on the back. Socialist Review, June, 165.

Stack P (1994) Out of character. Stack on the back. Socialist Review, June, 176.

Stack P (2002) Over the bottom line. Socialist Review. Available at:

http://www.socialistreview.org.uk/article.php?articlenumber=8136

Steen R (2011) The D'Oliveira affair: Cricket, 'race' and politics. In: Wagg S (ed.) Myths and Milestones in the History of Sport. Basingstoke: Palgrave Macmillan.

Steinberg D (1978) The workers sport internationals 1920-1928. Journal of Contemporary History 13(2): 233-251.

Stemple G (1981) Content analysis. In: Stemple G and Westley B (eds) Research Methods on Mass Communication. Englewood Cliffs, NJ: Prentice Hall, pp. 119-131.

Stone A (2005) Not a level playing field. Socialist Review, September. Available at: http://www.socialistreview.org.uk/article.php?articlenumber=9537

Sugden J (2005) Teaching and playing sport for conflict resolution and co-existence in Israel. International Review for the Sociology of Sport 41(2): 221-240. 
Tomlinson A and Whannel G (1994) Five-Ring Circus: Money, Power and Politics at the Olympic Games. London: Pluto Press.

Trotsky L (1974) Writings on Britain, vol. II. London: New Park Publications.

Trotsky L (1994) Problems of Everyday Life: Creating the Foundations for a New Society in Revolutionary Russia. New York: Pathfinder Press.

Trotsky L (2000) The newspaper and its readers. In: Trotsky L (ed) Problems of Everyday Life: Creating the Foundations for a New Society in Revolutionary Russia. New York: Pathfinder, pp. 149-159.

Vincent J (2004) Game, sex, and match: The construction of gender in British newspaper coverage of the 2000 Wimbledon Championships. Sociology of Sport Journal 21: 435-456.

Vincent J, Imwold C, Masemann V, et al. (2002) A comparison of selected 'Serious' and 'Popular' British, Canadian, and United States newspaper coverage of female and male athletes competing in the Centennial Olympic Games: Did female athletes receive equitable coverage in the 'Games of the Women'? International Review for the Sociology of Sport 37(3-4): 319-335.

Vincent J, Kian E, Pedersen P, et al. (2010) England expects: English newspapers' narratives about the English football team in the 2006 World Cup. International Review for the Sociology of Sport 45: 199223.

Walker T (2012) Olympic scandal is the tip of the iceberg at G4S. Socialist Worker, 21 July, 10.

Wanta W (2008) The coverage of sports in print media. In: Raney A and Bryant J (eds) Handbook of Sports and Media. New York: Routledge, pp. 111-122.

Wenner L (ed.) (1998) Media Sport. New York: Routledge.

Whannel G (1983) Blowing the Whistle: The Politics of Sport. London: Pluto Press. 
Wheeler R (1978) Organised sport and organised labour: The workers' sports movement. Journal of Contemporary History 13(2): 191-210.

Wheen F (2000) Karl Marx. London: Fourth Estate.

Zirin D (2005) What's My Name, Fool? Sports and Resistance in the United States. Chicago: Haymarket.

Zirin D (2008) People's History of Sports in the United States; 250 Years of Politics, Protest, People, and Play. New York: New Press.

Zirin D (2010) Bad Sports: How Owners Are Ruining the Games We Love. New York: Scribner.

Zirin D (2013) Game Over: How Politics Has Turned the Sports World Upside Down. New York: The New Press.

Zirin D and Edwards G (2012) Interview - Resistance: The best Olympic spirit. International Socialist Journal 135: 81-91.

\footnotetext{
${ }^{1}$ Marx did play chess very competitively (Wheen, 2000) and Engels was a keen fox-hunter, if one counts that as sport (Hunt, 2009).

${ }^{2}$ Officially titled the International Union of Red Sports and Gymnastics Associations.

${ }^{3}$ Those writing for communist party newspapers have viewed sport differently from those on the far left who see sport as bourgeois ideology. Silber's (2003) work on Lester Rodney and his writing for the US Communist Party's Daily Worker during the middle of the $20^{\text {th }}$ century, identifies how a sports section was developed to attract more readers to the paper. The British daily Morning Star, popular with those on the left of the British Labour Party and in trade union positions, has regularly covered sports events.
} 
${ }^{4}$ See Gumbrecht (2006) for a gentle, more appreciative interpretation of the beauty that can be found within sport.

${ }^{5}$ Pearlman claims these were collectively authored texts produced by those on the far left in France in the late 1960s and early 1970s.

${ }^{6}$ This estimate is based on personal conversations and correspondence with long-standing members of the party. Paul Foot (2000: xvi) notes that the collapse of the Communist Party in 1989 saw 'the SWP become by far the largest socialist grouping in the county'.

${ }^{7}$ I was not able to access the SW paper prior to this period. Those active during the $1960 \mathrm{~s}$ and $1970 \mathrm{~s}$ recall how the paper regularly covered the South African sporting boycott. The $S W$ did cover the 1978 FIFA World Cup in Argentina carrying a front-page headline (3 June 1978) which stated: 'Enjoy the goals, but remember the jails' (personal correspondence).

${ }^{8}$ The first series 1958-1969 contained 104 editions; the second series started in 1987 with the latest issue being 135. The other occasion was an interview with Dave Zirin (see section on London 2012).

${ }^{9}$ In 1990 the MP and former Chairman of the Conservative Party, Norman Tebbitt, questioned what he saw as a lack of patriotism amongst recent immigrants and their children. In particular, he asked whether those of South Asian and West Indian heritage were sufficiently 'British', loyal and supportive when the English cricket team played against India, Pakistan or the West Indies.

${ }^{10}$ Basil D'Oliveira was a South African cricketer. He was classified by the South Africa (SA) government as coloured and, when unable to play first-class cricket in his country, he emigrated to the UK. He was picked to represent England on a tour to South Africa in 1968, but the apartheid SA government questioned his inclusion. The tour was subsequently cancelled with the affair seen as a milestone in the isolation of SA from sporting competition (Steen, 2011).

${ }^{11}$ The SWP organise an annual, five-day event held in London. See www.marxismfestival.org.uk. From 1976 to 1990 the SWP held its annual Easter rally at Skegness. In addition to various political and cultural events, there was also a knockout football competition, the final of which took place after the closing rally. 